\title{
Evaluation of the Performance of the University Information Systems: Case of Moroccan Universities
}

\author{
Ayoub Gacim ${ }^{1}$, Hicham Drissi ${ }^{2}$, Abdelwahed Namir $^{3}$ \\ Laboratory of Information Technology and Modeling \\ Hassan II University, Faculty of Sciences Ben M'SIK, Casablanca, Morocco ${ }^{1,3}$ \\ Laboratory of Research and Prospects in Finance and Management \\ Hassan II University, National School of business and Management Casablanca, Morocco ${ }^{2}$
}

\begin{abstract}
The purpose of this paper is to develop a conceptual model of university information systems performance measurement. To do this resorted to the choice of 3E-3P model. This model proposes a development under the spectrum of the systemic approach. The objective is to provide a tool to decisionmakers in order to understand the dynamics of performance measurement. The model is based on a logic of decomposition of the global performance into three partial performances. The measurement is carried out at each pillar individually using a multi-criteria approach (MACBETH), and subsequently the consolidation of the three partial performances is carried out with the same multicriteria logic.
\end{abstract}

Keywords-Component; information system; performance; multicriteria modeling; university

\section{INTRODUCTION}

The evaluation of performance in the current administrative context is unanimously recognized as an essential factor in steering administrations. To measure this performance, decision-makers have to use performance indicators. Regarding the definition of the indicators, it is possible to make a distinction in the literature between the standards and the usual methods of piloting by indicators. In the first case finds repositories like ITIL, COBIT, Their goal is primarily to provide a structure and tools tailored to professionals from a particular sector. The repositories are based on a benchmark principle of the best practices encountered on the possible widest range of companies. Repositories are often used in practice because they provide the elements to be measured and allow quick apprehension of performance system. The conventional indicators provided are useful and it is interesting to use some of them. However, as soon as it is a question of a particular case they are not sufficient and the decision-maker must find how to enrich his performance measure. In the case of usual methods of piloting by indicators can differentiate between sectorized methods from optimization methods. In most cases the indicators target an element or a type of system elements. One of the weaknesses of these approaches seems to us to be the absence of an overall indicator providing a visibility across the system. The multicriteria aspect and the interactions between the criteria are often not taken into account. In addition, the detail they provide, particularly in the definition of indicators not allowing an adequate adaptation to the particular case of the decision-maker. The question becomes, then, how, beyond the indicators used, the decisionmaker can apprehend the performance as a whole. This article will be organized in four sections: (i) explanation and discussion of the problem, its nature and its difficulties, (ii) presentation and comparative study of the multicriteria methods available on the literature; (iii) construction and presentation of the model; and (iv) analysis and interpretation of results; and the article will be closed with a conclusion and perspective.

\section{PROBLEMATIC}

You cannot approach the performance of an organization without integrating the dimension of its IS and especially when it comes to service activities such as academic universities.

Several works try to include the intelligent dimension into the information system [1] like the trends in other fields [2] [3] but they don't integrate the efficiency of information system in the evaluation of the global performance [4] [5]. In addition, universities ranking is limited to the research dimension [6] which is easier to measure and evaluate, when they should be improving the information system to get better performance.

In this case the Information System is more than a driving factor, it is a successful information system which improves development, cost, innovation, and network in universities, and as a consequence it leads to obtain a competitive advantage [7]. It is in this context that the notion of "global performance" appears. This multidimensional concept makes it possible to go from a financial representation of the performance to more global approaches including several dimensions. Numerous examples justify this finding, notably the use of the commercial margin in the evaluation of economic performance; ROI (return on investment) in the evaluation of the return on invested capital; Turnover rate in the assessment of social and human performance; The $360^{\circ}$ method: as a tool allowing managers to be informed about the perception that their professional entourage have of the effectiveness of their behavior in contributing to their mission. This analysis, which focuses on the assessment of the contribution of information systems to the performance of Moroccan universities, is surrounded by the heterogeneous nature of performance criteria. Have found it essential to use a multi-faceted and multi-criteria decision support tool to converge and align selected criteria. To further enhance Campbell's assumption of 
coverage of all criteria and to respond to cost optimization logic; total control of operations; and the constraint of time, it is considered appropriate to synthesize this reflection on three aspects of performance evaluation in this case: Economy, Efficiency, Efficiency.

\section{Positioning THE SEARCH}

This approach is then interpretative-constructivist. Interpretative in the sense that it uses the arrangement between two modeling approaches, as well as a field investigation for the determination of IS performance criteria in Moroccan universities. Subsequently a tree modeling of these performance criteria according to the above model $3 \mathrm{E}-3 \mathrm{P}$ presented, these on one hand. On the other hand, the constructivist aspect of this work stands out in mathematical modeling, MACBETH [8] in essence and the results will be explained below. To provide a tool for reconstructing the reality of measuring the overall performance of IS in Moroccan universities. Modeling proposal is to explain the overall performance in three areas (technical, professional and process). Subsequently articulate these with the contributions and knowledge of the literature on the overall performance of IS.

\section{CHOiCE OF THE MulticRiteria Method}

The ambition stemming from mathematical modeling can be summed up in two essential points. First, propose a suitable multicriteria model and examine its empirical validity. Then check the overall performance of the IS in the Moroccan university. Thus, several models and theories were founded in the object. The table below summarizes the existing methods and their properties [9].
Following a bibliographic (Table I and Fig. 1) study and a comparison between the different multicriteria methods opted for the two methods AHP and Macbeth. They have properties like the simple operating principle; the mathematical consistency and the binary comparison principle that makes the evaluation work practical. Final choice will focus on the Macbeth method given the accessibility of the software. It facilitates the translation of the decision-makers perception and his appreciation of the performance in order to elicit his reasoning model.

\section{A. Figures and Tables}

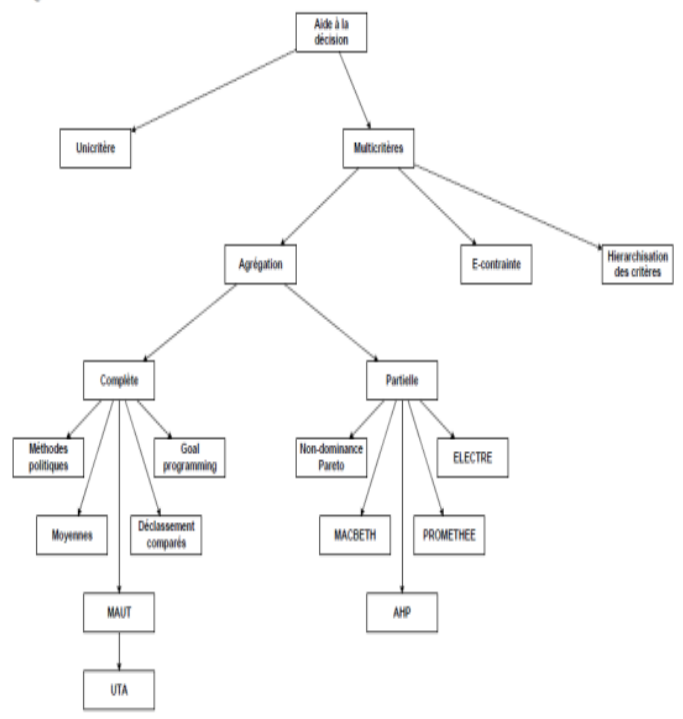

Fig. 1. Categorization of Decision Support Methods.

TABLE I. MULTICRITERIA METHOD COMPARAISON

\begin{tabular}{|c|c|c|c|c|}
\hline Method & Author & Consistency & Criteria & Software \\
\hline AHP & $\begin{array}{l}\text { SAATY } \\
\text { SCHÄRLIG } \\
\text { T'KINDT } \\
\text { BILLAUT }\end{array}$ & $\begin{array}{l}\text { Analytic hierarchy process relies on the hierarchical structure of } \\
\text { the problem consisting of goal levels, criteria. And alternatives. } \\
\text { For more details on multicriteria decisions [10] }\end{array}$ & $\begin{array}{l}\text { Tangible or } \\
\text { Intangible }\end{array}$ & EXPERT CHOICE \\
\hline MACBETH & $\begin{array}{l}\text { BANA E COSTA ET } \\
\text { VANSNIK }\end{array}$ & $\begin{array}{l}\text { An approach to measure attractiveness through a category-based } \\
\text { evaluation technique [8] }\end{array}$ & $\begin{array}{l}\text { Tangible or } \\
\text { Intangible }\end{array}$ & M-MACBETH \\
\hline TOPIS & $\begin{array}{l}\text { HWANG AND } \\
\text { YOON }\end{array}$ & $\begin{array}{l}\text { A multi-attribute decision-making technique (MADM) in which } \\
\text { alternatives are ranked according to their distance between the } \\
\text { ideal and negative ideal solution [11] }\end{array}$ & Tangible & TOPSIS SOLVER \\
\hline $\begin{array}{l}\text { THE STUDY OF } \\
\text { NON DOMINANCE }\end{array}$ & $\begin{array}{l}\text { BARICHARD } \\
\text { COLLETTE SIARRY }\end{array}$ & $\begin{array}{l}\text { Consists of dismissing dominated solutions. We say that a } \\
\text { solution } S 1 \text { dominates a solution } S 2 \text { in the sense of } n \text { criteria if } \\
\text { the performance of } S 1 \text { is at least equal to the performance of } S 2 \\
\text { on the } n \text { criteria and strictly superior on one criterion. [12] }\end{array}$ & Tangible & \\
\hline PROMETHEE & $\begin{array}{l}\text { BRANS } \\
\text { MARESCHAL }\end{array}$ & $\begin{array}{l}\text { Preference Ranking Organisation Method for Enrichment } \\
\text { Evaluations: the principle is to use the flow of classification. That } \\
\text { is to say the power of an action compared to others [13] }\end{array}$ & $\begin{array}{l}\text { Tangible or } \\
\text { Intangible }\end{array}$ & PROMCALC \\
\hline MAUT Methods & $\begin{array}{l}\text { FISHBURN } \\
\text { KEENEY } \\
\text { DYER }\end{array}$ & $\begin{array}{l}\text { Multi-Attribute Utility Theory : it seeks to define a utility } \\
\text { function that summarizes all criteria [14] }\end{array}$ & Tangible & $\begin{array}{l}\text { LOGICAL } \\
\text { DECISIONS }\end{array}$ \\
\hline ELECTRE & ROY & $\begin{array}{l}\text { Elimination and choice translating reality and its variants which } \\
\text { consists of constituting a core of action that outclasses the others. } \\
\text { The core is the set of actions that are not outperformed by any }\end{array}$ & $\begin{array}{l}\text { Tangible or } \\
\text { Intangible }\end{array}$ & ELECTRE IS \\
\hline
\end{tabular}




\section{Construction of the Performance Measurement MODEL}

The approach taken at the level of performance measurement as explained above is based on a multi-criteria concept in order to take into account the different factors influencing performance. Also, the logic of decomposition of the notion of global performance into components must be taken into account in order to facilitate the notion of measurement. But there remains the problem of consolidation of the partial measures carried out. Hence the adoption of a hierarchical concept that makes it possible both to perform partial. In [15] and [16], authors make measurements separately and at the same time allow an aggregation of the components of the performance into a single global dimension. The overall performance structure is composed of three pillars (3P) essential to know Processes, professionals and the technical platform [17]. Each pillar consists of a set of criteria that respect the representatively of the triplet (3E), economy, efficiency and effectiveness [18]. The tree structure then becomes of the following form: (Fig. 2).

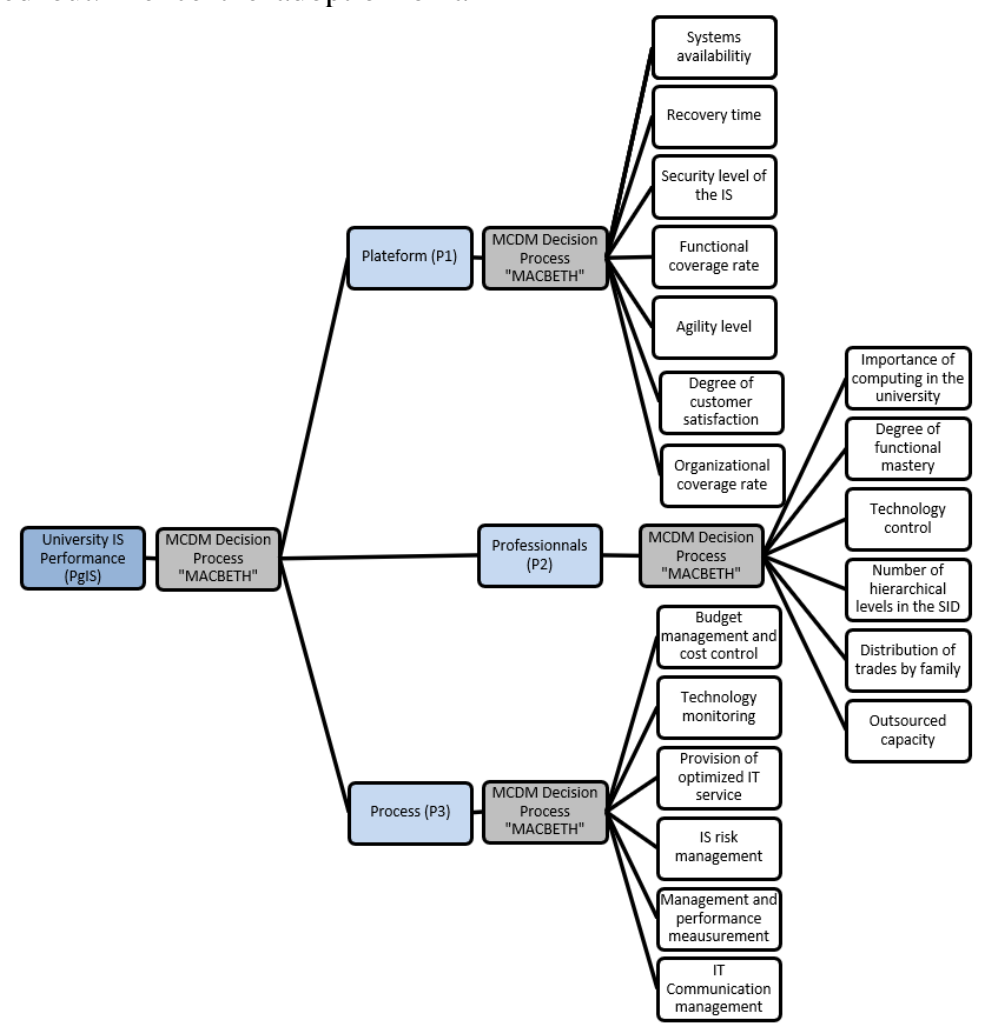

Fig. 2. Tree of the Performance Measurement Model.

\section{Operation OF THE MEASUREMENT MODEL (BASIC PRINCIPLE)}

The overall performance and the three pillars are evaluated on the basis of a P1 to P5 scale. P5 is the highest performance value and $\mathrm{P} 1$ is the lowest performance value. The measurement tool used in this approach as previously stated is the MACBETH multicriteria tool. The choice was justified and discussed in the section (comparative study between MC methods ...). View the many benefits it presents in this case. The measurement principle is based on an aggregation of the three partial components of the performance into a global measure [19]. It is the same for measuring the performance of each component based on its criteria [8]. It is a sequential iterative process that allows dissociated and individually realized evaluations but at the same time that will take into consideration each other to contribute to the overall judgment [20].

\section{ANALYSIS AND INTERPRETATION}

After engagement of the evaluation process with the help of experts using the M-MACBETH software, obtained the results of the partial evaluations and then injected them to re-evaluate the overall judgment that allowed us to obtain the final value of the overall performance. Below is a summary of the results obtained through the study of the performance of the two universities chosen by teamwork.

1) Case number I: Hassan the first university: The result obtained after measuring the performance of the first pillar (P1: .......) Based on its criteria (Fig. 3).

To extract from the summary shows that the performance of the first pillar is at level $2 / 5$. The tendency of evolution is towards level 3/5. The result obtained after measuring the performance of the second pillar (P2: .......) Based on its criteria (Fig. 4). 


Wh Table des cotes
\begin{tabular}{|c|r|r|r|r|r|r|r|r|}
\hline Options & \multicolumn{1}{|c|}{ Global } & \multicolumn{1}{|c|}{ N1 } & \multicolumn{1}{c|}{ N2 } & \multicolumn{1}{c|}{ N3 } & \multicolumn{1}{c|}{ N4 } & N5 & \multicolumn{1}{c|}{ N6 } & \multicolumn{1}{c|}{ N7 } \\
\hline [ toutes sup ] & 100.00 & 100.00 & 100.00 & 100.00 & 100.00 & 100.00 & 100.00 & 100.00 \\
\hline op 2 & 82.67 & 100.00 & 90.00 & 76.92 & 35.00 & 100.00 & 100.00 & 100.00 \\
\hline op 3 & 73.49 & 70.59 & 70.00 & 46.15 & 100.00 & 70.59 & 81.25 & 85.00 \\
\hline op 1 & 45.96 & 0.00 & 100.00 & 100.00 & 0.00 & 88.24 & 62.50 & 70.00 \\
\hline op 4 & 39.78 & 47.06 & 35.00 & 15.38 & 85.00 & 35.29 & 12.50 & 35.00 \\
\hline op 5 & 19.10 & 23.53 & 0.00 & 0.00 & 70.00 & 0.00 & 0.00 & 0.00 \\
\hline [toutes inf ] & 0.00 & 0.00 & 0.00 & 0.00 & 0.00 & 0.00 & 0.00 & 0.00 \\
\hline Poids: & 0.2653 & 0.0204 & 0.2245 & 0.1837 & 0.0612 & 0.1429 & 0.1020 \\
\hline
\end{tabular}

Fig. 3. Measuring the Performance of the First Pillar P1: Technical Platform UHP.

W1. Table des cotes
\begin{tabular}{|c|r|r|r|r|r|r|r|}
\hline Options & \multicolumn{1}{|c|}{ Global } & \multicolumn{1}{|c|}{ N1 } & \multicolumn{1}{c|}{ N2 } & \multicolumn{1}{c|}{ N3 } & \multicolumn{1}{c|}{ N4 } & \multicolumn{1}{c|}{ N5 } & \multicolumn{1}{c|}{ N6 } \\
\hline [ toutes sup ] & 100.00 & 100.00 & 100.00 & 100.00 & 100.00 & 100.00 & 100.00 \\
\hline op 3 & $\mathbf{8 8 . 8 8}$ & 100.00 & 100.00 & 100.00 & 50.00 & 52.63 & 86.67 \\
\hline op 4 & $\mathbf{6 2 . 8 7}$ & 23.53 & 76.47 & 76.47 & 25.00 & 100.00 & 100.00 \\
\hline op 2 & 54.75 & 88.24 & 23.53 & 52.94 & 75.00 & 26.32 & 73.33 \\
\hline op 1 & 38.57 & 64.71 & 0.00 & 41.18 & 100.00 & 0.00 & 53.33 \\
\hline op 5 & 20.12 & 0.00 & 47.06 & 0.00 & 0.00 & 78.95 & 0.00 \\
\hline [ toutes inf ] & 0.00 & 0.00 & 0.00 & 0.00 & 0.00 & 0.00 & 0.00 \\
\hline Poids: & 0.2500 & 0.1945 & 0.3056 & 0.0833 & 0.1389 & 0.0278 \\
\hline
\end{tabular}

Fig. 4. Measuring the Performance of the Second Pillar P2: the Professionals UHP.

The extract from the summary shows that: the performance of the second pillar is at the level $3 / 5$ with a tendency of evolution towards the level $4 / 5$. The result obtained after measuring the performance of the third pillar (P3: .......) Based on its criteria (Fig. 5).

The extract from the summary shows that/ the performance of the second pillar is at level $2 / 5$ with a tendency of evolution towards level 3/5. The result obtained after measuring the overall performance (PG: .......): From its components (the three pillars, P1, P2, P3) (Fig. 6).

The excerpt of the summary shows that: the overall performance is at the $3 / 5$ level with a trend towards level $2 / 5$.

2) Case number II: IBN ZOHR university: The result obtained after measuring the performance of the first pillar (P1: .......) Based on its criteria (Fig. 7).

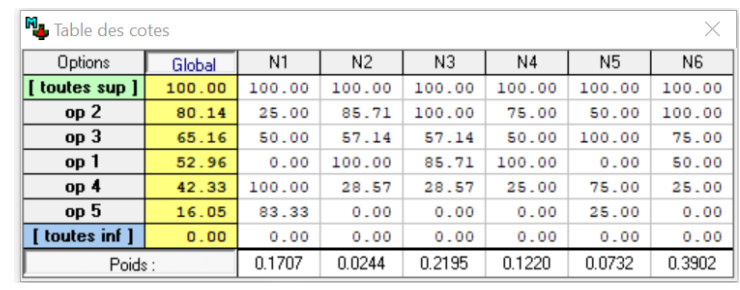

Fig. 5. Measuring the Performance of the Third Pillar P3: the Processes UHP.

\begin{tabular}{|c|c|c|c|c|}
\hline \multicolumn{5}{|c|}{ Wh Table des cotes } \\
\hline Options & Global & N1 & N2 & N3 \\
\hline [ toutes sup ] & 100.00 & 100.00 & 100.00 & 100.00 \\
\hline op 3 & 85.76 & 81.82 & 100.00 & 76.92 \\
\hline op 2 & 84.41 & 100.00 & 57.14 & 100.00 \\
\hline op 1 & 46.49 & 45.45 & 35.71 & 53.85 \\
\hline op 4 & 46.06 & 36.36 & 71.43 & 30.77 \\
\hline op 5 & 0.00 & 0.00 & 0.00 & 0.00 \\
\hline [ toutes inf ] & 0.00 & 0.00 & 0.00 & 0.00 \\
\hline \multicolumn{2}{|l|}{ Poids } & 0.0909 & 0.3636 & 0.5454 \\
\hline
\end{tabular}

Fig. 6. Overall Performance Measurement Result of the Three Pillars UHP.

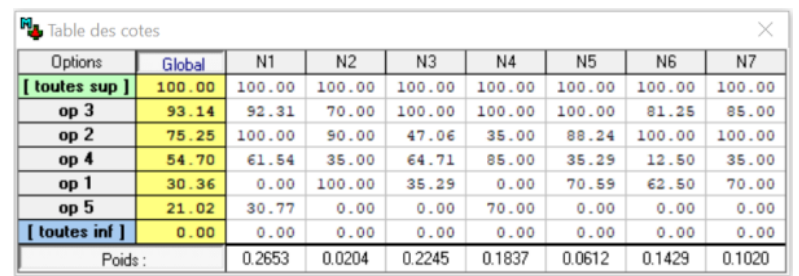

Fig. 7. Measuring the Performance of the First Pillar P1: Technical Platform UIZ.

The extract from the summary shows that: the performance of the first pillar is at the level $3 / 5$ with a tendency of evolution towards the level 2/5. The result obtained after measuring the performance of the second pillar (P2: .......) Based on its criteria (Fig. 8).

The extract from the summary shows that: the performance of the second pillar is at the level $3 / 5$ with a tendency of evolution towards the level 2/5.The result obtained after measuring the performance of the third pillar (P3: .......) Based on its criteria (Fig. 9).

The extract from the summary shows that: the performance of the second pillar is at level $2 / 5$ with a tendency of evolution towards level 3/5.The result obtained after measuring the overall performance (PG: .......): From its components (the three pillars, P1, P2, P3) (Fig. 10).

\begin{tabular}{|c|c|c|c|c|c|c|c|}
\hline \multicolumn{8}{|c|}{ Wable des cotes } \\
\hline Options & Global & $\mathrm{N} 1$ & N2 & N3 & $\mathrm{N} 4$ & N5 & N6 \\
\hline [ toutes sup ] & 100.00 & 100.00 & 100.00 & 100.00 & 100.00 & 100.00 & 100.00 \\
\hline op 3 & 88.88 & 100.00 & 100.00 & 100.00 & 50.00 & 52.63 & 86.67 \\
\hline op 2 & 77.28 & 88.24 & 23.53 & 126.67 & 75.00 & 26.32 & 73.33 \\
\hline op 4 & 59.87 & 23.53 & 76.47 & 66.67 & 25.00 & 100.00 & 100.00 \\
\hline op 1 & 36.18 & 64.71 & 0.00 & 33.33 & 100.00 & 0.00 & 53.33 \\
\hline op 5 & 20.12 & 0.00 & 47.06 & 0.00 & 0.00 & 78.95 & 0.00 \\
\hline [ toutes inf ] & 0.00 & 0.00 & 0.00 & 0.00 & 0.00 & 0.00 & 0.00 \\
\hline \multicolumn{2}{|l|}{ Poids: } & 0.2500 & 0.1945 & 0.3056 & 0.0833 & 0.1389 & 0.0278 \\
\hline
\end{tabular}

Fig. 8. Measuring the Performance of the Second Pillar P2: the Professionals UIZ.

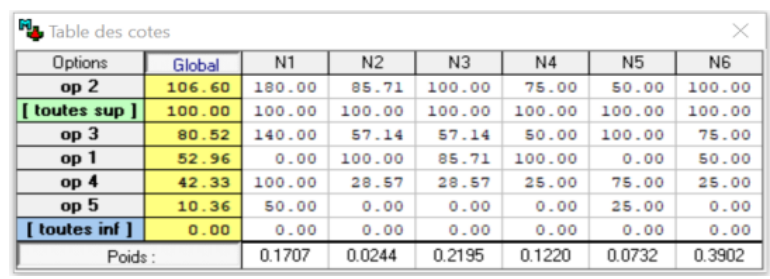

Fig. 9. Measuring the Performance of the Third Pillar P3: the Processes UIZ.

Ty Table des cotes
\begin{tabular}{|c|r|r|r|r|}
\hline Options & \multicolumn{1}{|c|}{ Global } & \multicolumn{1}{c|}{ N1 } & \multicolumn{1}{c|}{ N2 } & \multicolumn{1}{c|}{ N3 } \\
\hline [ toutes sup ] & 100.00 & 100.00 & 100.00 & 100.00 \\
\hline op 2 & 90.91 & 100.00 & 75.00 & 100.00 \\
\hline op 3 & 87.83 & 137.50 & 100.00 & 71.43 \\
\hline op 4 & 39.45 & 62.50 & 50.00 & 28.57 \\
\hline op 1 & 34.74 & 25.00 & 25.00 & 42.86 \\
\hline op 5 & $\mathbf{0 . 0 0}$ & 0.00 & 0.00 & 0.00 \\
\hline [ toutes inf ] & $\mathbf{0 . 0 0}$ & 0.00 & 0.00 & 0.00 \\
\hline \multicolumn{2}{|r|}{ Poids: } & 0.0909 & 0.3636 & 0.5454 \\
\hline
\end{tabular}

Fig. 10. Overall Performance Measurement Result of the Three Pillars UIZ. 
The extract of the summary shows that: the overall performance is at level $2 / 5$ with a tendency of evolution towards level $3 / 5$.

\section{SUMMARY OF THE RESUlTS}

The two tables below (Table II and Table III) are the results of the evaluation work of this case study.

The synthesis mentioned above is the result of the analysis of the data resulting from the multi-criteria modeling object of the mobilization of the MACBETH tool.

The first table represents the summary of all the criteria of Hassan Premier University.

While the second table represents the summary of all the criteria of IBNOZOHR University.

Thus these tables demonstrate the level of performance of each field by generating both the trend and the judgment value following the evaluation of the three main pillars (P1 platform $\mathrm{P} 2$ professional $\mathrm{P} 3$ process) across all criteria. To visualize and compare the level of the current performance with that planned consider useful and meaningful the use of the radar graphic representation and this to estimate the trend of the performance.

The graphical representation of the UHP's radar (Fig. 11), observe an upward trend in the overall performance of the information system. The observation shows that this has important long-term evolution prospects.

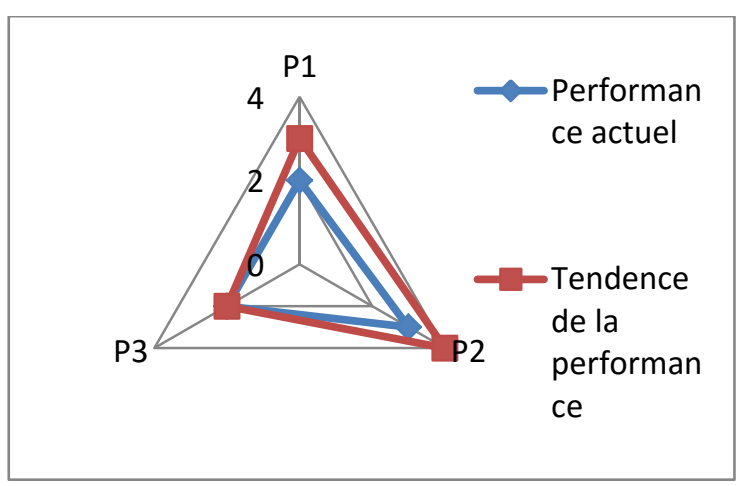

Fig. 11. Representation Current Performance and UHP Trend.

TABLE II. UHP EVALUATION DATA

\begin{tabular}{|c|c|c|c|c|c|c|c|c|c|c|c|}
\hline \multirow[b]{2}{*}{ Title of the criterion } & \multirow[b]{2}{*}{$\begin{array}{l}\text { Crite } \\
\text { ria } \\
\text { code }\end{array}$} & \multirow[b]{2}{*}{$\begin{array}{l}\text { Perform } \\
\text { ance by } \\
\text { criterion }\end{array}$} & \multirow[b]{2}{*}{$\begin{array}{l}\text { Pilla } \\
\text { rs }\end{array}$} & \multicolumn{2}{|c|}{$\begin{array}{l}\text { Level of } \\
\text { performance }\end{array}$} & \multicolumn{2}{|c|}{$\begin{array}{l}\text { Trend of } \\
\text { performance } \\
\text { (Prospective } \\
\text { development) }\end{array}$} & \multicolumn{2}{|c|}{$\begin{array}{l}\text { Level of } \\
\text { performance }\end{array}$} & \multicolumn{2}{|c|}{$\begin{array}{l}\text { Trend of } \\
\text { performance } \\
\text { (Prospective } \\
\text { development) }\end{array}$} \\
\hline & & & & $\begin{array}{l}\text { Perform } \\
\text { ance }\end{array}$ & $\begin{array}{l}\text { Judgm } \\
\text { ent } \\
\text { value }\end{array}$ & $\begin{array}{l}\text { Perform } \\
\text { ance }\end{array}$ & $\begin{array}{l}\text { Judgm } \\
\text { ent } \\
\text { value } t\end{array}$ & $\begin{array}{l}\text { Perform } \\
\text { ance }\end{array}$ & $\begin{array}{l}\text { Judgm } \\
\text { ent } \\
\text { value }\end{array}$ & $\begin{array}{l}\text { Perform } \\
\text { ance }\end{array}$ & $\begin{array}{l}\text { Judgm } \\
\text { ent } \\
\text { value }\end{array}$ \\
\hline Systems availability & P11 & 2 & \multirow{7}{*}{ 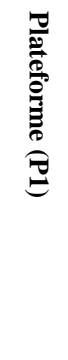 } & \multirow{7}{*}{2} & \multirow{7}{*}{82,67} & \multirow{7}{*}{3} & \multirow{7}{*}{73,49} & \multirow{19}{*}{3} & \multirow{19}{*}{85,76} & \multirow{19}{*}{2} & \multirow{19}{*}{84,41} \\
\hline Recovery time & P12 & 1 & & & & & & & & & \\
\hline Security level of the IS & P13 & 1 & & & & & & & & & \\
\hline Functional coverage rate & P14 & 3 & & & & & & & & & \\
\hline Agility level & P15 & 2 & & & & & & & & & \\
\hline Degree of customer satisfaction & P16 & 2 & & & & & & & & & \\
\hline Organizational coverage rate & P17 & 2 & & & & & & & & & \\
\hline $\begin{array}{l}\text { Importance of computing in the } \\
\text { university }\end{array}$ & $\mathrm{P} 21$ & 3 & \multirow{6}{*}{$\begin{array}{l}7 \\
\overline{0} \\
0 \\
0 \\
0.0 \\
0 \\
0 \\
0 \\
0 \\
0\end{array}$} & \multirow{6}{*}{3} & \multirow{6}{*}{$\mathbf{8 8 , 8 8}$} & \multirow{6}{*}{4} & \multirow{6}{*}{62,87} & & & & \\
\hline Degree of functional mastery & $\mathrm{P} 22$ & 3 & & & & & & & & & \\
\hline Technology control & $\mathrm{P} 23$ & 3 & & & & & & & & & \\
\hline $\begin{array}{l}\text { Number of hierarchical levels } \\
\text { in the SID }\end{array}$ & P24 & 1 & & & & & & & & & \\
\hline Distribution of trades by family & P25 & 4 & & & & & & & & & \\
\hline Outsourced capacity & P26 & 4 & & & & & & & & & \\
\hline $\begin{array}{l}\text { Budget management and cost } \\
\text { control }\end{array}$ & P31 & 4 & \multirow{6}{*}{ 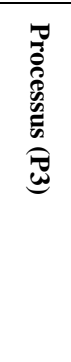 } & \multirow{6}{*}{2} & \multirow{6}{*}{80,14} & \multirow{6}{*}{2} & \multirow{6}{*}{65,16} & & & & \\
\hline Technology monitoring & P32 & 1 & & & & & & & & & \\
\hline $\begin{array}{l}\text { Provision of optimized IT } \\
\text { service }\end{array}$ & P33 & 2 & & & & & & & & & \\
\hline IS risk management & P34 & 1 & & & & & & & & & \\
\hline $\begin{array}{l}\text { Management and performance } \\
\text { measurement }\end{array}$ & P35 & 3 & & & & & & & & & \\
\hline $\begin{array}{l}\text { IT Communication } \\
\text { management }\end{array}$ & P36 & 2 & & & & & & & & & \\
\hline
\end{tabular}


TABLE III. UIZ EVALUATION DATA

\begin{tabular}{|c|c|c|c|c|c|c|c|c|c|c|c|}
\hline \multirow[b]{2}{*}{ Title of the criterion } & \multirow[b]{2}{*}{$\begin{array}{l}\text { Crite } \\
\text { ria } \\
\text { code }\end{array}$} & \multirow[b]{2}{*}{$\begin{array}{l}\text { Perform } \\
\text { ance by } \\
\text { criterion }\end{array}$} & \multirow[b]{2}{*}{$\begin{array}{l}\text { Pilla } \\
\text { rs }\end{array}$} & \multicolumn{2}{|c|}{$\begin{array}{l}\text { Level of } \\
\text { performance }\end{array}$} & \multicolumn{2}{|c|}{$\begin{array}{l}\text { Trend of } \\
\text { performance } \\
\text { (Prospective } \\
\text { development) }\end{array}$} & \multicolumn{2}{|c|}{$\begin{array}{l}\text { Level of } \\
\text { performance }\end{array}$} & \multicolumn{2}{|c|}{$\begin{array}{l}\text { Trend of } \\
\text { performance } \\
\text { (Prospective } \\
\text { development) }\end{array}$} \\
\hline & & & & $\begin{array}{l}\text { Perform } \\
\text { ance }\end{array}$ & $\begin{array}{l}\text { Judgm } \\
\text { ent } \\
\text { value }\end{array}$ & $\begin{array}{l}\text { Perform } \\
\text { ance }\end{array}$ & $\begin{array}{l}\text { Judgm } \\
\text { ent } \\
\text { value t }\end{array}$ & $\begin{array}{l}\text { Perform } \\
\text { ance }\end{array}$ & $\begin{array}{l}\text { Judgm } \\
\text { ent } \\
\text { value }\end{array}$ & $\begin{array}{l}\text { Perform } \\
\text { ance }\end{array}$ & $\begin{array}{l}\text { Judgm } \\
\text { ent } \\
\text { value }\end{array}$ \\
\hline Systems availability & P11 & 2 & \multirow{7}{*}{ 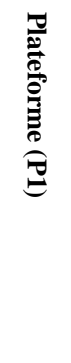 } & \multirow{7}{*}{3} & \multirow{7}{*}{93,14} & \multirow{7}{*}{2} & \multirow{7}{*}{75,25} & \multirow{19}{*}{2} & \multirow{19}{*}{90,91} & \multirow{19}{*}{3} & \multirow{19}{*}{87,83} \\
\hline Recovery time & $\mathrm{P} 12$ & 1 & & & & & & & & & \\
\hline Security level of the IS & P13 & 3 & & & & & & & & & \\
\hline Functional coverage rate & P14 & 3 & & & & & & & & & \\
\hline Agility level & P15 & 3 & & & & & & & & & \\
\hline Degree of customer satisfaction & P16 & 2 & & & & & & & & & \\
\hline Organizational coverage rate & P17 & 2 & & & & & & & & & \\
\hline $\begin{array}{l}\text { Importance of computing in the } \\
\text { university }\end{array}$ & $\mathrm{P} 21$ & 3 & \multirow{6}{*}{ 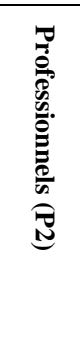 } & \multirow{6}{*}{3} & \multirow{6}{*}{88,88} & \multirow{6}{*}{2} & \multirow{6}{*}{77,28} & & & & \\
\hline Degree of functional mastery & P22 & 3 & & & & & & & & & \\
\hline Technology control & $\mathrm{P} 23$ & 3 & & & & & & & & & \\
\hline $\begin{array}{l}\text { Number of hierarchical levels } \\
\text { in the SID }\end{array}$ & $\mathrm{P} 24$ & 1 & & & & & & & & & \\
\hline Distribution of trades by family & P25 & 4 & & & & & & & & & \\
\hline Outsourced capacity & P26 & 4 & & & & & & & & & \\
\hline $\begin{array}{l}\text { Budget management and cost } \\
\text { control }\end{array}$ & P31 & 4 & \multirow{6}{*}{ 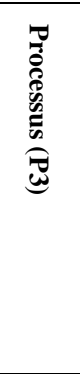 } & \multirow{6}{*}{2} & \multirow{6}{*}{106,6} & \multirow{6}{*}{3} & \multirow{6}{*}{80,52} & & & & \\
\hline Technology monitoring & P32 & 1 & & & & & & & & & \\
\hline $\begin{array}{l}\text { Provision of optimized IT } \\
\text { service }\end{array}$ & P33 & 2 & & & & & & & & & \\
\hline IS risk management & P34 & 1 & & & & & & & & & \\
\hline $\begin{array}{l}\text { Management and performance } \\
\text { measurement }\end{array}$ & P35 & 3 & & & & & & & & & \\
\hline $\begin{array}{l}\text { IT Communication } \\
\text { management }\end{array}$ & P36 & 2 & & & & & & & & & \\
\hline
\end{tabular}

From the analysis of the graphical representation of the radar of the UIZ (Fig. 12), is noted a downward trend in the overall performance of the information system. This observation demonstrates a limitation of evolution and longterm control.

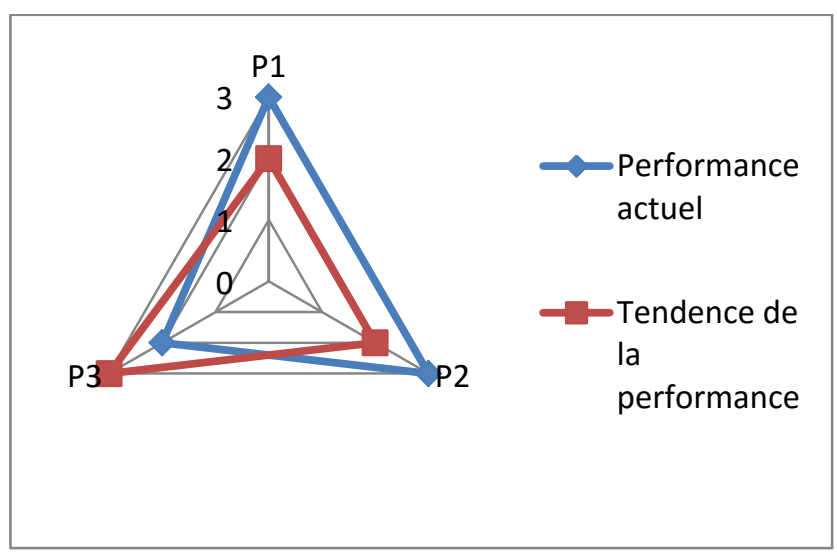

Fig. 12. Representation Current Performance and UIZ Trend.

\section{CONCLUSION AND PERSPECTIVES}

From By way of conclusion, the results obtained show that the management of information systems within the universities in sample is beginning to be structured. But it still lacks efficiency given the results obtained in terms of the mobilization of the means put at their disposal.

Thus results-based management and performance is very embryonic at the level of information systems. Two recommendations seem to us to be crucial: the generalization of multicriteria evaluation in all Moroccan universities; give more importance to the SI function in the organization chart and in the strategic decisions of all university bodies: university councils, school councils, scientific committees. The insufficiencies deciphered by multicriteria model, motivates us to propose research perspectives for more supervision to this problematic. Intend to update the multicriteria evaluation model periodically and permanently on other research projects. The performance indicators recommended at the end of this research work will be proposed in the form of a balanced scorecard in an article that links the SI to management control. 
This research shows the importance of the MACBETH multi-criteria approach in elaboration of performance measurement system of Information System University. The tool is based on the comparison of the difference in attractiveness between different alternatives. This comparison is performed by experts. This limitation obligates searchers to choose carefully the experts concerned with prudence and transparent to be able to apply perfectly the multicriteria for the measure of performance. In order to avoid this limitation, an evaluation questionnaire was sent to the manager of the SI as well as the presidents of the universities and to a panel of project managers. Only the answers and information from the interviews with the members of the universities Hassan first of Settat and that of IBNOZOHR in Agadir were sufficiently complete and exhaustive. The totality of the results of the evaluation of the information system cannot be published in detail because of their confidential nature. Only the general features of the multicriteria model have been addressed.

\section{REFERENCES}

[1] R. Kresimir, B. G. Marijana, and M. Vlado, "Development of the Intelligent System for the Use of University Information System," Procedia Engineering, vol. 69, pp. 402-409, 2014.

[2] K. Douaioui, M. Fri, C. Mabroukki, and E. A. Semma, "The interaction between industry 4.0 and smart logistics: concepts and perspectives," in 2018 International Colloquium on Logistics and Supply Chain Management (LOGISTIQUA), Tangier, 2018, pp. 128-132.

[3] K. Douaioui, M. Fri, C. Mabrouki, and E. A. Semma, "Smart port: Design and perspectives," in 2018 4th International Conference on Logistics Operations Management (GOL), Le Havre, 2018, pp. 1-6.

[4] S. El Gibari, T. Gómez, and F. Ruiz, "Evaluating university performance using reference point based composite indicators," Journal of Informetrics, vol. 12, no. 4, pp. 1235-1250, Nov. 2018.

[5] X. Zhang and W. Shi, "Research about the university teaching performance evaluation under the data envelopment method," Cognitive Systems Research, vol. 56, p. a, Aug. 2019.

[6] C. Daraio, A. Bonaccorsi, and L. Simar, "Rankings and university performance: A conditional multidimensional approach," European Journal of Operational Research, vol. 244, no. 3, pp. 918-930, Aug. 2015.
[7] Jaf, R., Xinping, X., \& Sabr Jaf, S. (2012). The Effect of the Strategic Information Systems (SIS) on the Achievement Competitive Advantage Practical in Samples of Iraqi Banks. International Conference of Intelligent Systems Design and Engineering Application (hal. 954 959). IEEE.

[8] Bana e Costa C.A. and J.C. Vansnick. MACBETH: An Interactive Path Towards the Construction of Cardinal Value Functions. International Transactions in Operational Research, 1(4):387-500, 1994.

[9] P. LORINO, « Méthodes et pratiques de la performance, le guide du pilotage », Editions de l'organisation, 1997, p.18.

[10] Fatimazahra Bentaleb, Charif Mabrouki, Alami Semma. Dry Port Development: A Systematic Review. J ETA Maritime Sci. 2015; 3(2): 75-96.

[11] Keeney R.L. and H. Raiffa. Decision with Multiple Objectives: Preference and Value Tradeoffs. Cambridge.

[12] Parmenter, D., Measuring Performance In Difficult Times, Finance \& Management, avril 2009, p. 6-11.

[13] Brans, J. P., Vincke, P., \&Mareschal, B. (1986). How to select and how to rank projects: The PROMETHEE method; European journal of operational research, 24(2), 228-238.

[14] Fatimazahra Bentaleb, Charif Mabrouki, Alami Semma. Key Performance Indicators Evaluation and Performance Measurement in Dry Port-Seaport System: A Multi Criteria Approach. J ETA Maritime Sci. 2015; 3(2): 97-116.

[15] Berrah, L., Mauris, G., Vernadat, F., 2004. Information aggregation in industrial performance measurement: rationales, issue and definitions. International Journal of Production Research, 42(20), 211-225.

[16] Berrah, L., Mauris, G., Haurat, A., Foulloy, L., 2000. Global vision and performance indicators for an industrial improvement approach. Computers in Industry, 43, 211-225.

[17] Saaty T.L. Fundamentals of decision making and priority theory with the Analytic Hierarchy Process, RWS Publications (1994).

[18] Roy, B. (1991); The outranking approach and the foundations of ELECTRE methods, Theory and decision, 31(1), 49-73.

[19] Hwang, C. K. Yoon Multiple attribute decision making: methods and applications Springer-Verlag, New York (1981).

[20] Fatimazahra Bentaleb; Charif Mabrouki \&Alami Semma (2015) A Multi-Criteria Approach for Risk Assessment of Dry Port-Seaport System, Supply Chain Forum: An International Journal, 16:4, 32-49. 